\title{
思春期の問題行動に対する青年期のとらえ直し
}

\author{
「学校に行きたくない」体験に対する親と教師の関わり方について \\ ○鹿嶌達哉 \\ (広島国際大学心理科学部) \\ キーワード : 不登校，青年期，とらえ直し
}

Reframing School Nonattendance by Adolescent Students

\section{Tatsuya KASHIMA}

(Faculty of Psychological Science, Hiroshima International University) Key Words: school nonattendance, adolescence, reframing

\section{目 的}

不登校は思春期の状況や発達課題と密接に関連しているた め、その対応は思春期全般への理解が求められる。不登校に ならなかった生徒にも数日間休んだもの、なりかけたもの、 休みたいと思ったものなど「学校に行きたくない」体験をし たものは多い。そのとき親と教師はどのように対応してきた のだろうか。その対応は登校のための働きかけだけではなく 教師・学校、親・家庭との関係が表れる一方で、その関係に 影響を及ぼす。また、そのような体験は青年期にどのように とらえ直されているだろうか。鹿嶌はいじめ (2008教心, 2010) 不登校 (2013, 2017 教心) に対する青年期のとらえ直しを研 究してきた。本研究では「学校に行きたくない」体験」に対 する親と教師の対応に焦点を当て、受講による不登校と思春 期に対する理解の変容を明らかにする。

$$
\text { 方 法 }
$$

調査対象：2006〜2010 年度, 2 大学において発達心理学系の 科目を受講した 649 名が不登校をテーマとした受講後記した 感想 197 の中からとらえ直しに関するもの 84 を対象とした。 対象者と以下の【】内の数字の詳細は鹿嶌（2013）を参照。

\section{結 果 と 考 察}

「学校に行きたくない」体験への対応は 3 つた大別された。 〔「行かなくていいよ」] $: 「$ 何も言わない」「無理に行けとは言 わない」「行かなくていいよ」【11,99〜114】と対応されると 子どもは、「よかった」【110】、「嬉しかった」【102】と思う、 楽になる【100, 111】、安心する【101】、気楽に休める【109】、 学校に行く気になる【111】、心の整理ができる【11】、気分転 換できる【103】、母は味方だと思う【106】体験をした。また、 一緒に家にいる【105】、仕事を休む【106】、遊び（映画）に 行く【107】、父と遊びに行き母と料理をする【12】など親が 一緒に過ごすこともあった。また、「休んでいい」と言われる ことで学校を休まずに行けた例もあった【104, 112〜114】。学 校に行きたくない」と言いながら毎日通っていた学生もいた 【135】。「休んでいいよ」と言われることで一日だけ休み、翌 日から登校した例もみられた【108, 115】

〔話をきいて理解してもらう〕学校を休んだときや休みそう になったときに、親に話を聞いてもらい、理解される【14, 15, 98, 123〜136】体験も多い。話を聞いてくれることにより 嬉しい【126】、心が軽くなる【128】、秘密を守ってくれて言 いたいことが言える【129】、母は味方と安心できる【134】と 感じていた。最初は親にわからない、親を信じていなかった が親に話してわかってもらえたりすっきりしたりした例も見 られた【123, 133】。母ではなく、父が話をきいてくれたり 【125, 131】、やさしくメール励ましてくれたりする【130】こ とあった。また、母が理解し父が怒ることによりいろいろな 考え方ができるようになった【15】。さらに、祖母が話を聞い てくれた例も報告された。

[行きなさい] : 行きなさいと言われた【13,116〜122】こと
に対して、今は感謝している【119】、よかったと思う【120】、 fine play【117】と今は評価している。無理矢理登校させた場 合でも、「助けてあげるから頑張りなさい」【13】、やさしく話 をきく【116】、行きたくない理由をわかってくれていた【118】 などのフォローがみられた。また、納得のいく理由を求めら れて答えられず学校に行った【122】もあった。

[親に対する期待と配慮]：親にはわかってくれる【141】、気 ら゙いてほしい【142】と期待する場合と、親には期待【73】も 信用【74】もしない例があった。しているが、親の期待が子 どもを苦しめ【144】、プレッシャーになることもある【146】。 親に理解されないと気持ちを伝えられないし【16】つらい思 いをする【143】ため、不登校を許す親をうらやましく感じる 【145】。映像資料の姉のがまん【41】、母に期待していないこ と【46】、母が味方ではないことについて、自分の体験と重ね て共感する学生がいた。親につらい思いをさせたくないとい う理由で話せなかったり学校に通ったりする例【137〜140】 も報告された。母を信じている【137】、親が悲しむ【138, 139】、 絶対相談したくない【140】と親を「守って」いた。

[親に求める対応法]: 親の対応法について自分の体験に基づ き【17】、友だちのように【136】、学校に関しては何も突っ込 まない【147】、転機を待つ【27】ことを期待していた。 [教師による支援]：不登校に対して教師は毎日迎えに来る 【10】、体調を気遣う【77】、部活への出席を促す【78】など の対応に加え、交換ノート【39】や日記【79】、ジュースを飲 みながら話をきく【80】、ゲームをすることで生徒とコミュニ ケーションをとっていた。不登校の生徒の机を前に置く配慮 【81】もみられた。保健室の先生は話しやすく【83】、しっか り話を聞く【84】と評価された。

[教師への批判]：その一方で教師に対する不信や批判もみ られた。対等に見ていない【85】、関わりが弱い【87】、気持 ちをわかろうとしていない【93】、わかってもらえないと諦め る【96】、あまり気にしないで信じもしない【97】など教師と の関係、対応する時間がない【86】、理解していない【88, 92】、 見て見ぬふりをする【92】、配慮がすくない【89】、生徒に任 せて負担をかけている【90, 91, 94】、余計な手出しをするなど 対応に関するものがあつた。

「学校に行きたくない」体験に対して大切なのは「行かな くていいよ」「話を聞く」「行きなさい」という対応の型では なく、その文脈を形成している親子関係や親の見方だと思わ れる。教師の適切な対応を高く評価する一方で、教師との関 係や対応に対する批判もみられたが、これも思春期といら文 脈でとらえる必要があると思われる。

\section{引用文献}

鹿嶌達哉（2010）思春期の問題行動に対する青年期のとらえ 直し 広島国際大学教育論叢 第 2 号 3-13 (教心，2008) 鹿鴧達哉（2013）思春期の問題行動に対する青年期のとらえ 直し (2) 広島国際大学教育論叢 第 5 号 17-28(教心, 2017) 